Article

\title{
DNA Compaction and Charge Inversion Induced by Organic Monovalent Ions
}

\author{
Wenyan Xia, Yanwei Wang, Anthony Yang and Guangcan Yang * \\ School of Physics and Electronic Information, Wenzhou University, Wenzhou 325035, China; \\ xiawenyan147@163.com (W.X.); wangyw@wzu.edu.cn (Y.W.); yanggc77@gmail.com (A.Y.) \\ * Correspondence: yanggc@wzu.edu.cn; Tel.: +86-577-8668-9033; Fax: +86-577-8668-9010
}

Academic Editor: Helmut Schlaad

Received: 14 January 2017; Accepted: 23 March 2017; Published: 30 March 2017

\begin{abstract}
DNA condensation and charge inversion usually occur in solutions of multivalent counterions. In the present study, we show that the organic monovalent ions of tetraphenyl chloride arsenic $\left(\mathrm{Ph}_{4} \mathrm{As}^{+}\right)$can induce DNA compaction and even invert its electrophoretic mobility by single molecular methods. The morphology of condensed DNA was directly observed by atomic force microscopy (AFM) in the presence of a low concentration of $\mathrm{Ph}_{4} \mathrm{As}^{+}$in DNA solution. The magnetic tweezers (MT) measurements showed that DNA compaction happens at very low $\mathrm{Ph}_{4} \mathrm{As}^{+}$concentration $(\leq 1 \mu \mathrm{M})$, and the typical step-like structures could be found in the extension-time curves of tethering DNA. However, when the concentration of $\mathrm{Ph}_{4} \mathrm{As}^{+}$increased to $1 \mathrm{mM}$, the steps disappeared in the pulling curves and globular structures could be found in the corresponding AFM images. Electrophoretic mobility measurement showed that charge inversion of DNA induced by the monovalent ions happened at $1.6 \mathrm{mM} \mathrm{Ph}_{4} \mathrm{As}^{+}$, which is consistent with the prediction based on the strong hydrophobicity of $\mathrm{Ph}_{4} \mathrm{As}^{+}$. We infer that the hydrophobic effect is the main driving force of DNA charge inversion and compaction by the organic monovalent ion.
\end{abstract}

Keywords: DNA compaction; charge inversion; monovalent ions; hydrophobic effect

\section{Introduction}

DNA is one of the most important biological polyelectrolytes, and is highly negatively charged in solution. The highly-charged stiff polymer can be condensed into compact structures by multivalent ions and many other condensing agents [1-3]. The understanding of DNA compaction is not only important for the study of fundamental biological processes such as chromosome compacting, but also for the development of new gene carriers in therapeutic applications [4-6]. On the other hand, DNA compaction is closely related with its charge screening, because structural packaging requires an effective screening of the negative charges on DNA. The process is generally considered to be related to the neutralization-or more likely overcompensation-of the DNA electric charge [7-9]. Overcompensation or charge inversion occurs when the charge of counterions surrounding the DNA surface are greater than the bare charge of polyelectrolyte itself. For DNA systems, the effect seems to be found almost exclusively in the case of multivalent ions in aqueous solution [7,10-14]. Charge inversion was also observed in mixtures of charged polyelectrolytes with oppositely charged oligomers [7,15], polymers [16-24], colloids [18,25-28], or micelles [29]. The related DNA compaction from bulk solution critically depends on the valence of the counterions, and a valence of three or larger is required to overcome the inherently large electrostatic repulsive barrier between the like-charged polyelectrolytes [30-33].

However, the underlying microscopic mechanism of attraction between like-charged macroions such as DNA and their charge inversion is still controversial. There have been a number of theoretical studies aimed at elucidating the fundamental physical mechanisms responsible for DNA compaction 
and charge inversion $[34,35]$. All these systems are strongly correlated; the electrostatic interactions are strong and the effects of thermal motions, translational, or conformational entropy of chains is small. It has been proposed that electrostatic correlations are dominant and lead to charge inversion in the case of counterions with valences larger than two near strongly-charged interfaces [8]. In the case of monovalent ions, electrostatic correlations are weak and no charge inversion is expected. Recently, Martin-Molina et al. [36] proposed a new mechanism for the charge inversion of colloids in electrolyte solutions based on the hydrophobic effect. They observed charge inversion due to the organic monovalent ion $\mathrm{Ph}_{4} \mathrm{As}^{+}$in colloids, and the effect was attributed to the hydrophobic effect. In the present study, we introduce the organic monovalent ion $\mathrm{Ph}_{4} \mathrm{As}^{+}$into a DNA system and find that it not only provokes the charge inversion of DNA, but also leads to DNA compaction, which is the first experimental evidence for DNA compaction induced by monovalent cations. The phenomenon seems to be similar to the poor solvent effect of neutral condensing agents such as ethanol in DNA solution [37].

\section{Experimental Procedures}

\subsection{Materials}

Tetraphenylarsonium chloride $\left(\mathrm{Ph}_{4} \mathrm{AsCl}\right)$ is a tetrahedron consisting of a central As atom covalently bonded to four hydrophobic groups (the phenyl $-\mathrm{C}_{6} \mathrm{H}_{5}$ rings). This highly hydrophobic cation is widely employed as a reference cation in electrochemistry because of the relatively small importance of electrostatics in its hydration free energy in different media; this is due to its large size (diameter $d=0.94 \mathrm{~nm}$ ), its symmetry, and its monovalent character. Tetraphenylarsonium chloride $\left(\mathrm{C}_{24} \mathrm{H}_{20} \mathrm{AsCl} \cdot \mathrm{HCl} \cdot \mathrm{xH}_{2} \mathrm{O}\right)$, sodium bromide $(\mathrm{NaBr})$, and $\mathrm{MgCl}_{2}$ were purchased from Sigma-Aldrich, (Sain Louis, MO, US). Bacterial $\lambda$-DNA was purchased from New England Biolabs (Ipswich, MA, US), and it had a concentration of $500 \mathrm{ng} / \mu \mathrm{L}$ as obtained from the manufacturer. We could use $\lambda$-DNA directly without further treatment in atomic force microscopy (AFM), but DNA modification was necessary before pulling in magnetic tweezers (MT). The solvent we used was $1 \mathrm{mM}$ sodium bromide aqueous solution, and water was deionized and purified by a Millipore system and had a conductivity less than $1 \times 10^{-6} \Omega^{-1} \mathrm{~cm}^{-1}$. Mica for AFM imaging was cut into approximately $1 \mathrm{~cm}^{2}$ square pieces, and their surfaces were always freshly cleaved before use. All chemical agents were used as received, and all measurements were repeated at least twice to obtain consistent results.

\subsection{AFM Imaging}

The sample preparation procedure is similar to the one in our previous work [36]. It can be briefly described as follows: mica disks of diameter one centimeter attached to magnetic steel disks were used as substrates for DNA adsorption. For each sample, the final concentration of DNA was $1 \mathrm{ng} / \mu \mathrm{L}$, corresponding to $3 \mu \mathrm{M}$ of phosphate groups, and a drop of about $15 \mu \mathrm{L}$ of $\mathrm{Ph}_{4} \mathrm{As}^{+}$mixture was deposited for $3 \mathrm{~min}$ on a freshly-cleaved mica surface. The surface was rinsed with distilled water and dried with a gentle flow of nitrogen gas.

A multi-mode atomic force microscope (SPM-9600, Shimadzu, Kyoto, Japan) was used for DNA imaging in the presence of $\mathrm{Ph}_{4} \mathrm{As}^{+}$. All AFM images were captured in the conventional ambient tapping mode, with scan speeds of $\approx 2 \mathrm{~Hz}$ and data collection at $512 \times 512$ pixels. All the images were processed manually using off-line analysis software equipped with the microscope.

\subsection{Magnetic Tweezers Experiment}

Magnetic tweezers are common tools for manipulating single molecules, such as tethering a condensed DNA molecule [38]. A transverse MT system was composed of an inverted microscope and charge coupled device (CCD) controlled by a personal computer, which is schematically shown in Figure 1. In our experiments, the ends of DNA were coated with biotin and digoxin by biochemical method, and the surfaces of paramagnetic beads were covered with streptavidin. A coverslip with one 
side polished was sandwiched between two glass slides, and was used as a flow chamber by sealing the sealing the open sides of the structure. The polished sidewall was silylated and functionalized with anti-digoxin in order to link with the dig-end of DNA. The other end of DNA was linked to a paramagnetic bead by the streptavidin-biotin bond. The force was applied to the paramagnetic bead by adjusting the permanent magnet which is installed on a micromanipulator. A video camera was used to monitor the image of the tethered structure, and the positions of paramagnetic beads were recorded in real-time. The analysis of the extension and force was determined by a tracking algorithm based on correlation function [39].

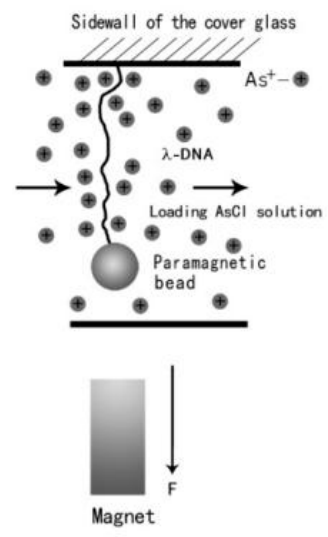

Figure 1. A schematic diagram of magnetic tweezers.

Various concentrations of $\mathrm{Ph}_{4} \mathrm{AsCl}$ solution were mixed with $\mathrm{NaBr}$ solution $(1 \mathrm{mM})$, then an equal volume of DNA solutions containing $10 \mathrm{mM} \mathrm{MgCl}_{2}$ were added for magnetic tweezers measurement. The solution was incubated for $30 \mathrm{~min}$ at least at room temperature, and introduced into the flow cell by using a syringe pump. In a typical measurement, we moved the magnet from some distance to some position close to a paramagnetic bead, thus applying a magnetic force on the suspended bead. When a fixed magnetic force was applied to the bead, we monitored the end-to-end length of DNA in real-time to measure its conformational change.

\subsection{Electrophoretic Mobility Measurement by Dynamic Light Scattering (DLS)}

The electrophoresis-mobility measurements were carried out by using a dynamic light scattering device of Malvern Zetasizer Nano ZS90 (Malvern Instruments Ltd., Worcestershire, UK) equipped with the patented M3-PALS technique. The laser source is a He-Ne gas laser $(\lambda=633 \mathrm{~nm})$ and the light scattering is collected by an avalanche photodiode mounted on the goniometer arm to the direction of the incident radiation. The DNA samples were diluted to a concentration of $1 \mathrm{ng} / \mu \mathrm{L}$ in a buffer solution containing $1 \mathrm{mM} \mathrm{NaBr}$ and $5 \mathrm{mM} \mathrm{MgCl}$; then, different concentrations of $\mathrm{Ph}_{4} \mathrm{As}^{+}$were added. All measurements were carried out after $5 \mathrm{~min}$ incubation at room temperature. During the measurement, $1 \mathrm{~mL}$ of DNA solution was used, and the sample cell was kept at $25^{\circ} \mathrm{C}$ temperature.

\section{Results and Discussion}

\subsection{Observation by AFM}

We attempted to observe the change in morphology of the DNA- $\mathrm{As}^{+}$complexes in the presence of different concentrations of $\mathrm{Ph}_{4} \mathrm{As}^{+}$in solution. In our experiment, $\mathrm{MgCl}_{2}$ solution (5 mM) was added into the buffer to adsorb DNA on the mica surface. The AFM images of DNA-As ${ }^{+}$complexes on the mica surface are shown in Figure 2. For reference, we start by imaging DNA alone in the same buffer condition as used for the complexes (Figure 2A). We can see that the DNA molecules are well separated on the surface, and have relaxed morphologies with no compaction loops. From Figure 2B-F, 
the corresponding molar ratio between arsenic cations and the phosphate group of DNA varies from 3.33 to 333.3. As shown in Figure 2B, there are few intermolecular contacts at lower $\mathrm{As}^{+}$concentrations, but individual molecules have an increased number of intramolecular loops with increasing $\mathrm{As}^{+}$ concentration. However, when $\left[\mathrm{As}^{+}\right]>0.1 \mathrm{mM}$, typical condensed structures were observed, and a part of the DNA structures were still in the coiled conformation. A condensed center appeared (Figure 2C), and DNA highly looped around this point, as shown in Figure 2D. The compaction grew gradually when the concentration of $\mathrm{As}^{+}$increased further (Figure 2E), and at the highest concentration (Figure 2F), we can see even more compacting patterns (e.g., globules) on the mica surface.

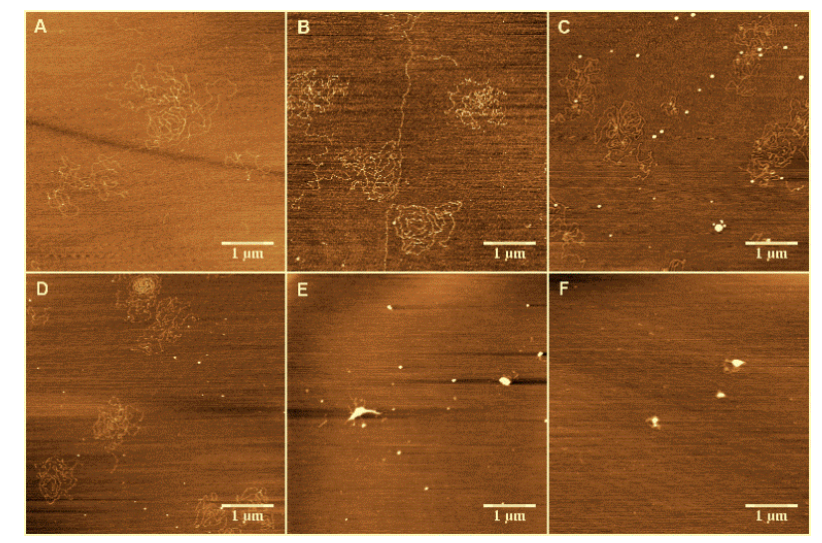

Figure 2. AFM observation of DNA complexes. Panel (A) $\lambda$-DNA in $5 \mathrm{mM} \mathrm{Mg}^{2+}$ solution; Panels (B-F) DNA conformations at different concentrations $\left(0.01,0.05,0.1,0.5\right.$ and $1 \mathrm{mM}$, respectively) of $\mathrm{As}^{+}$in $5 \mathrm{mM} \mathrm{Mg}^{2+}$ buffer.

AFM may modify the actual morphology of DNA in $\mathrm{As}^{+}$solution. We have previously shown that the treatment of condensed DNA adsorbed to a surface only reduces the molecules' heights but maintains their lateral dimensions [37]. Thus, AFM images flatten the morphology of DNA condensates with their original compacting structure. However, the condensed DNA is adsorbed on a mica surface and only binds to the surface loosely. Despite the interactions between the substrate and the polyelectrolytes (which can modify the structure of complexes), there is a nice correlation between the macroscopic phase diagram and the AFM observations. We think that the reason for this phenomenon is similar to the mechanism of alcohol [37] leading to DNA compaction. Since DNA is a semiflexible polymer molecule and the attractive forces between DNA segments are rather weak, the DNA molecules in poor solvent tend to form compact toroidal structures in solution due to the equilibrium between the exclusion and bending energy.

To enhance DNA adsorption on the mica surface for imaging, we used a buffer containing a high concentration of $\mathrm{Mg}^{2+}(5 \mathrm{mM})$. To rule out its effect on DNA compaction, we performed the same experiments in $1 \mathrm{mM}$ of $\mathrm{Mg}^{2+}$ - the lowest concentration to deposit DNA on a mica surface. The results are similar, and are shown in Figure 3. We can see that the DNA condensed from loose structures to highly-compact globules with increasing $\mathrm{As}^{+}$concentration in the low concentration of $\mathrm{Mg}^{2+}$. Thus, we can deduce that the DNA compaction is caused by arsenic ion rather than the effect of magnesium ion. Actually, the DNA condensing ability of $\mathrm{Ph}_{4} \mathrm{As}^{+}$is much weaker than spermine, as shown in Figure 4 , where the effect of $0.5 \mathrm{mM} \mathrm{As}^{+}$is comparable with $0.01 \mathrm{mM}$ spermine. 


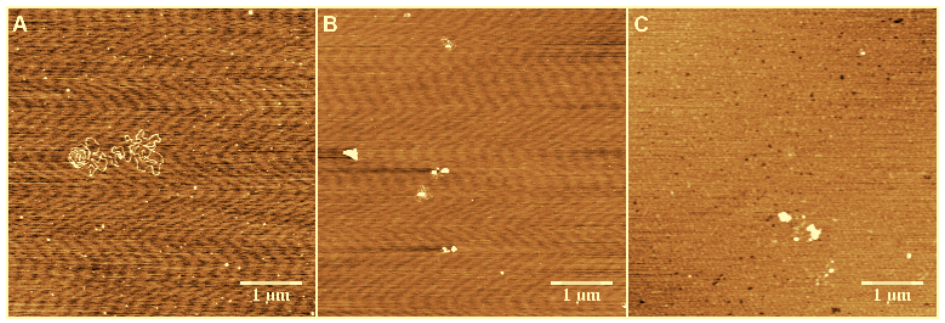

Figure 3. The structure of DNA in mixture solution of various concentrations ((A) $0.1 \mathrm{mM}$; (B) $0.5 \mathrm{mM}$; (C) $1 \mathrm{mM})$ of $\mathrm{As}^{+}$and $1 \mathrm{mM} \mathrm{Mg}{ }^{2+}$.

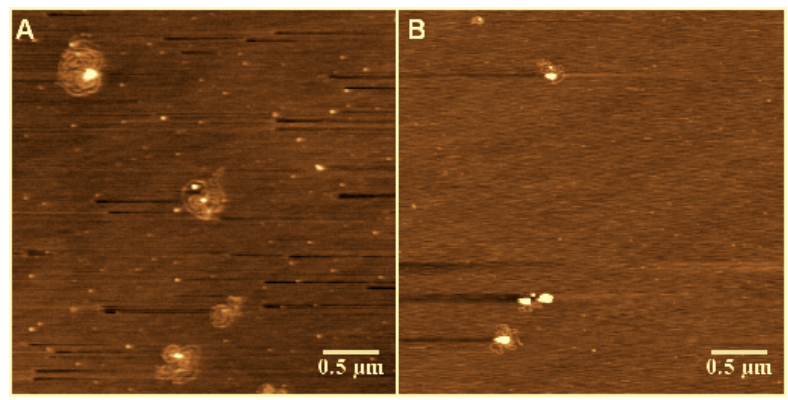

Figure 4. DNA structures in solution of (A) $0.01 \mathrm{mM}$ spermine and (B) $0.5 \mathrm{mM} \mathrm{As}^{+}$.

\subsection{Tethering of Single DNA Molecules}

DNA tethering was achieved in a magnetic tweezers (MT) setup, as described above. We first put the microsphere-bound DNA molecules in $\mathrm{NaBr}$ buffer $(1 \mathrm{mM})$ and magnesium ion $(5 \mathrm{mM})$ into the flow cell and incubated them for $30 \mathrm{~min}$ at room temperature. Then, we could find that some paramagnetic beads had tethered to the surface of the sidewall through a single DNA molecule. In the absence of any condensing agents, we found that the extension of DNA was close to $16 \mu \mathrm{m}$ under high extension $(>10 \mathrm{pN})$. Then, about $400 \mu \mathrm{L}$ of different concentrations of $\mathrm{Ph}_{4} \mathrm{AsCl}$ solution were loaded into the flow cell and stretched the DNA by approaching the magnet to the bead, or releasing the bead by moving back the magnet while the extension of the DNA molecule was monitored in real-time. The results of the DNA tethering are shown in Figures 5 and 6. From Figure 5A, we can see the stepwise shrinking of the DNA extension when a constant $0.5 \mathrm{pN}$ pulling force was exerted upon the bead at low concentration of $\mathrm{Ph}_{4} \mathrm{AsCl}(1 \mu \mathrm{M})$. After the DNA molecule condensed to a compact state, we had to apply much larger force ( $5.4 \mathrm{pN}$ in this case) to unravel the condensed structure, as shown in Figure 5B. We could repeat the shrinking and unraveling many times, and the processes was reversible in our experiment. When the concentration of $\mathrm{Ph}_{4} \mathrm{AsCl}$ in the buffer increased, the tethering force increased accordingly to unravel the condensed DNA structures. We could still see the stepwise structure in the shrinking or pulling curves of DNA molecules when the concentration of $\mathrm{Ph}_{4} \mathrm{AsCl}$ is not greater than $0.5 \mathrm{mM}$, as shown in Figures 6 and 7. However, the stepwise structure disappeared in the shrinking curves when the concentration of $\mathrm{As}^{+}$reached $1 \mathrm{mM}$, as shown in Figure 7C. We infer than a more compact structure (e.g., globule) was formed in the high concentration condition. 

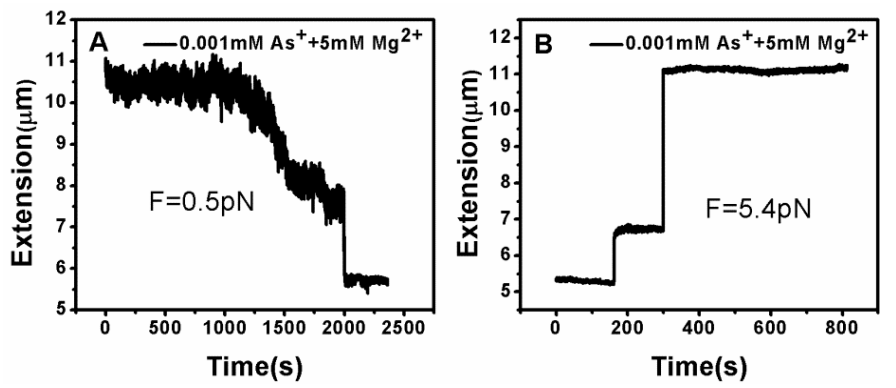

Figure 5. DNA extension-time curves under the influence of $\mathrm{Ph}_{4} \mathrm{As}^{+}$. (A) The shrinking of DNA at pulling force $0.5 \mathrm{pN}$; (B) unraveling of DNA condensed structures.
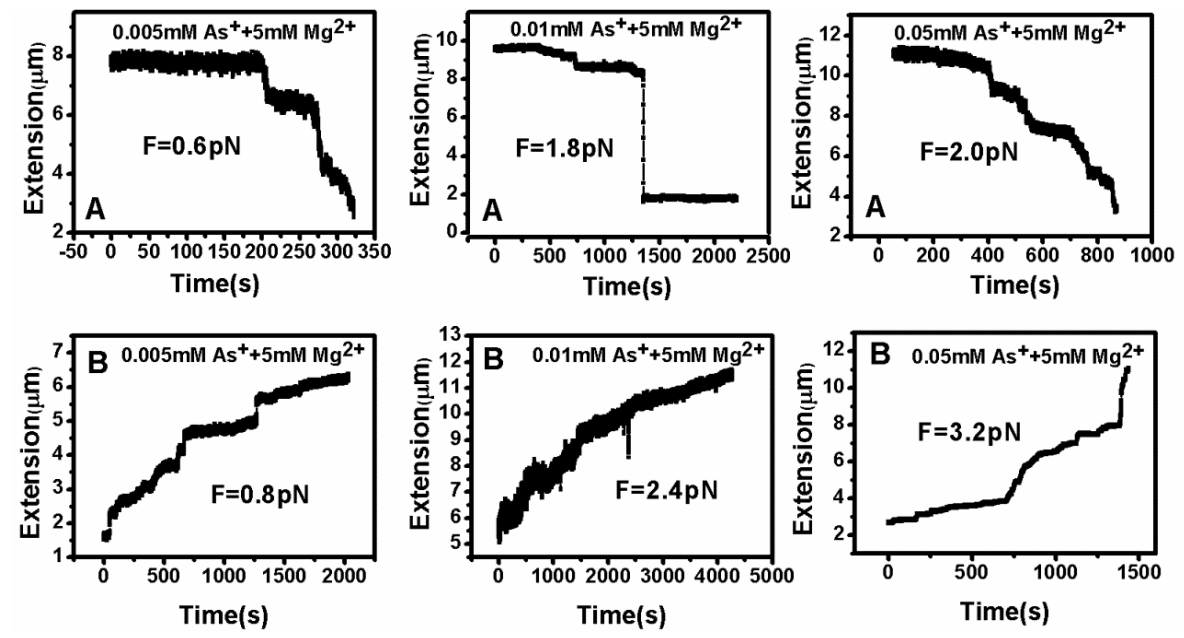

Figure 6. DNA extension-time curves when (A) contracting and (B) stretching at various $\mathrm{Ph}_{4} \mathrm{As}^{+}$concentrations.
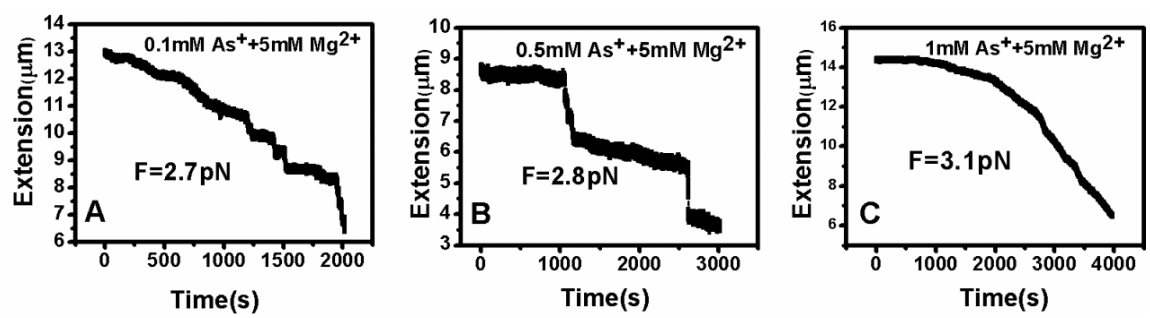

Figure 7. DNA extension-time curves at high concentrations ((A) $0.1 \mathrm{mM}$; (B) $0.5 \mathrm{mM}$; (C) $1 \mathrm{mM})$ of $\mathrm{Ph}_{4} \mathrm{As}^{+}$.

By analyzing the tethering curves, we concluded that the hydrophobic driving force mechanism is similar to the effect of poor solvent. However, the former is much stronger, since the tethering force is on the order of a few $\mathrm{pN}$, while the shrinking force is difficult to measure in the case of ethanol solution [35]. For consistency and reproducibility, we repeated our tethering cycle under each condition at least 10 times. The curve of condensing force is presented in Figure 8. The details of pulling forces and DNA particle sizes are presented in Tables S1-S3. 


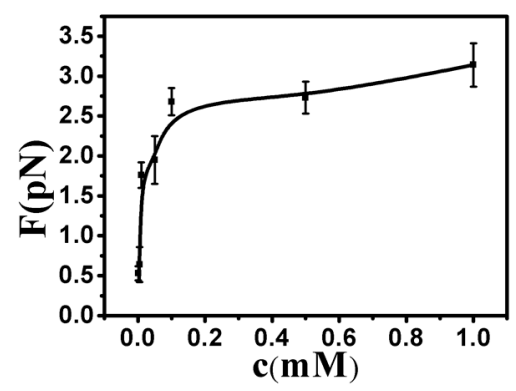

Figure 8. The curve of condensing force at different concentrations of $\mathrm{Ph}_{4} \mathrm{As}^{+}$.

\subsection{Electrophoretic Mobility of DNA}

We measured the electrophoretic mobility of DNA in the mixture solution with different concentrations of $\mathrm{Ph}_{4} \mathrm{As}^{+}$and $5 \mathrm{mM} \mathrm{MgCl}$ by dynamic light scattering technique. The result is shown in Figure 9. We can see that the mobility of DNA changed from negative to positive values with the increasing $\mathrm{As}^{+}$concentration. The mobility approached zero at about $1.75 \mathrm{mM}$ of $\mathrm{Ph}_{4} \mathrm{As}^{+}$. For cation concentrations larger than this, the mobility reversed from negative to positive, implying that charge inversion occurred. Meanwhile, the size of DNA complex decreased with $\mathrm{As}^{+}$concentration. When the concentrations of $\mathrm{As}^{+}$were $0.01,0.05,0.1,0.5,1,2$, and $3 \mathrm{mM}$, the corresponding particle sizes of DNA condensates were 310, 300, 210, 200, 180, 182, and $180 \mathrm{~nm}$, respectively, and the errors were $\pm 20 \mathrm{~nm}$.

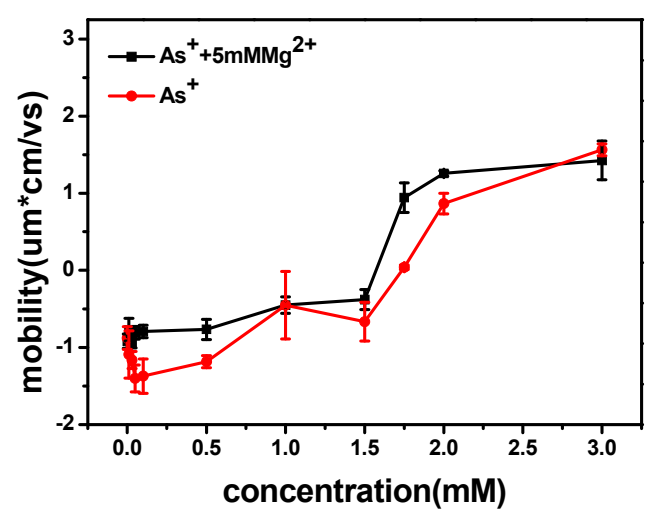

Figure 9. Electrophoretic mobility of DNA vs. the concentration of $\mathrm{Ph}_{4} \mathrm{As}^{+}$.

The mechanism of DNA charge reversal is similar to colloid charge inversion, the hydrophobic effect as a driving force for charge inversion. This mechanism is able to induce charge inversion at low concentrations of monovalent ions containing hydrophobic functional groups, and saturation effects appearing at higher concentrations.

Following the similar analysis in Reference [36], the critical concentration of counterions in solution when charge inversion occurs can be expressed as

$$
c_{B}^{I}=\frac{\left|\sigma_{0}\right|}{e d} \exp \left(\Delta \mu^{0} / k_{B} T\right)
$$

where $\Delta \mu^{0}=\mu_{S}^{0}-\mu_{B}^{0}$ is the difference in free energy between the dehydrated ion at close proximity to the colloid and the hydrate ion in bulk electrolyte, $d$ is the diameter of the counter ions, and $\sigma_{0}$ is the bare charge density of DNA. For the current system, where $d \approx 1 \mathrm{~nm}$, hydration energy is about $-5 k_{\mathrm{B}} T$, and bare surface charge is about $1.0 \mathrm{e} / \mathrm{nm}^{2}$, one obtains $c_{\mathrm{B}}^{\mathrm{I}}=1.6 \mathrm{mM}$. The measured value of charge inversion is about $1.75 \mathrm{mM}$, as shown in Figure 9, where charge inversion is observed for 
DNA in water at $298 \mathrm{~K}$ in the presence of low concentrations of a monovalent large organic cation [36]. The observed critical concentration is in agreement with the predicted value by hydrophobicity. It is noticeable that Equation (1) might only be applicable for a weakly charged system. DNA is a highly charged system where the correlation effect is significant and a more sophisticated theory is needed. In spite of the restriction, we can still use it as a preliminary estimation.

\section{Conclusions}

In summary, we found for the first time that the organic monovalent ions of tetraphenyl chloride arsenic $\left(\mathrm{Ph}_{4} \mathrm{As}^{+}\right)$can induce DNA compaction and its charge inversion, which is contradictory to the common understanding that charge inversion occurs only if the valence of counterions is $Z \geq 3$. These findings were confirmed by magnetic tweezers measurements, atomic force microscopy (AFM) imaging, and dynamic light scattering (DLS).

DNA compaction is usually involved the first-order phase transition between elongated and compact states, although some chemical species cause shrinkage of DNA to be much different from the transition [40]. DNA compaction occurs in one mode or mixed modes among all-or-none compaction, progressive compaction, and adsorption and wrapping, depending on condensing agents and solvents. The DNA compaction in $\mathrm{Ph}_{4} \mathrm{As}^{+}$solution is in a progressive compaction mode, which is directly shown in their AFM images (Figures 2 and 3). Since the electrostatic interaction between monovalent ions and DNA is not able to induce its compaction or charge inversion, we infer that the main driving force of DNA charge inversion and compaction by the organic monovalent ion $\mathrm{Ph}_{4} \mathrm{As}^{+}$is the hydrophobic effect.

Supplementary Materials: The following are available online at www.mdpi.com/2073-4360/9/4/128/s1, Table S1: The condensing force of DNA at different concentrations of $\mathrm{Ph}_{4} \mathrm{As}^{+}$, Table S2: The unravelling force of DNA at different concentrations of $\mathrm{Ph}_{4} \mathrm{As}^{+}$, Table S3: The particle size of DNA at different concentrations of $\mathrm{Ph}_{4} \mathrm{As}^{+}$.

Acknowledgments: We thank Ruxia Wang and Yang Chen for their help in experiments and helpful discussions. This work is supported by the National Natural Science Foundation of China (11274245, 10974146, 11304232).

Author Contributions: Guangcan Yang and Yanwei Wang conceived and designed the experiments; Wenyan Xia and Anthony Yang performed the experiments; Yanwei Wang and Wenyan Xia analyzed the data; Guangcan Yang, Wenyan Xia and Anthony Yang wrote the paper.

Conflicts of Interest: The authors declare no conflict of interest.

\section{References}

1. Bloomfield, V.A. DNA condensation by multivalent cations. Biopolymers 1997, 44, 269-282. [CrossRef]

2. Teif, V.B.; Bohinc, K. Condensed DNA: Condensing the concepts. Prog. Biophys. Mol. Biol. 2011, 105, $208-222$. [CrossRef] [PubMed]

3. Nguyen, T.; Rouzina, I.; Shklovskii, B. Reentrant condensation of DNA induced by multivalent counterions. J. Chem. Phys. 2000, 112, 2562-2568. [CrossRef]

4. Vijayanathan, V.; Thomas, T.; Thomas, T.J. DNA nanoparticals and development of DNA delivery vehicles for gene therapy. Biochemistry 2002, 41, 14085-14094. [CrossRef] [PubMed]

5. Thomas, T.J.; Tajmir-Riahi, H.; Thomas, T. Polyamine-DNA interactions and development of gene delivery vehicles. Amino Acids 2016, 48, 2423-2431. [CrossRef] [PubMed]

6. Tan, X.; Lu, X.; Jia, F.; Liu, X.; Sun, Y.; Logan, J.K.; Zhang, K. Blurring the role of oligonucleotides: Spherical nucleic acids as a drug delivery vehicle. J. Am. Chem. Soc. 2016, 138, 10834-10837. [CrossRef] [PubMed]

7. Besteman, K.; van Eijk, K.; Lemay, S. Charge inversion accompanies DNA condensation by multivalent ions. Nat. Phys. 2007, 3, 641-644. [CrossRef]

8. Grosberg, A.Y.; Nguyen, T.T.; Shklovskii, B.I. Colloquium: The physics of charge inversion in chemical and biological systems. Rev. Mod. Phys. 2002, 74, 329-345. [CrossRef]

9. Nguyen, T.T.; Shklovskii, B.I. Model of inversion of DNA charge by a positive polymer: Fractionalization of the polymer charge. Phys. Rev. Lett. 2002, 89, 018101. [CrossRef] [PubMed] 
10. Besteman, K.; Zevenbergen, M.A.; Heering, H.A.; Lemay, S.G. Direct observation of charge inversion by multivalent ions as a universal electrostatic phenomenon. Phys. Rev. Lett. 2004, 93, 170802. [CrossRef] [PubMed]

11. Yu, L.; Guang, Y.; Yan, W. A dynamic light scattering study of counter-ions condensation on DNA. Acta Phys. Sin. 2013, 62, 118702.

12. Luan, B.; Aksimentiev, A. Electric and electrophoretic inversion of the DNA charge in multivalent electrolytes. Soft Matter 2010, 6, 243-246. [CrossRef] [PubMed]

13. Wang, Y.; Wang, R.; Cao, B.; Guo, Z.; Yang, G. Single molecular demonstration of modulating charge inversion of DNA. Sci. Rep. 2016, 6, 38628. [CrossRef] [PubMed]

14. Qiu, S.; Wang, Y.; Cao, B.; Guo, Z.; Chen, Y.; Yang, G. The suppression and promotion of DNA charge inversion by mixing counterions. Soft Matter 2015, 11, 4099-4105. [CrossRef] [PubMed]

15. Raspaud, E.; Pelta, J.; de Frutos, M.; Livolant, F. Solubility and charge inversion of complexes of DNA and basic protein. Phys. Rev. Lett. 2006, 97, 068103. [CrossRef] [PubMed]

16. Kabanov, A.V.; Kabanov, V. DNA complexes with polycations for the delivery of gene material into cells. Bioconjug. Chem. 1995, 6, 7-20. [PubMed]

17. Petzold, G.; Nebel, A.; Buchhammer, H.-M.; Lunkwitz, K. Preparation and characterization of different polyelectrolyte complexes and their application as flocculants. Colloid Polym. Sci. 1998, 276, 125-130. [CrossRef]

18. Buchhammer, H.-M.; Petzold, G.; Lunkwitz, K. Salt effect on formation and properties of interpolyelectrolyte complexes and their interactions with silica particles. Langmuir 1999, 15, 4306-4310. [CrossRef]

19. Kekkonen, J.; Lattu, H.; Stenius, P. Adsorption kinetics of complexes formed by oppositely charged polyelectrolytes. J. Colloid Interface Sci. 2001, 234, 384-392. [CrossRef] [PubMed]

20. Choosakoonkriang, S.; Lobo, B.A.; Koe, G.S.; Koe, J.G.; Middaugh, C.R. Biophysical characterization of PEI/DNA complexes. J. Pharm. Sci. 2003, 92, 1710-1722. [CrossRef] [PubMed]

21. Mengarelli, V.; Auvray, L.; Zeghal, M. Phase behaviour and structure of stable complexes of oppositely charged polyelectrolytes. Europhys. Lett. 2009, 85, 58001. [CrossRef]

22. Mengarelli, V.; Zeghal, M.; Auvray, L.; Clemens, D. Phase behavior and structure of stable complexes between a long polyanion and a branched polycation. Phys. Rev. E 2011, 84, 021805. [CrossRef] [PubMed]

23. Störkle, D.; Duschner, S.; Heimann, N.; Maskos, M.; Schmidt, M. Complex formation of DNA with oppositely charged polyelectrolytes of different chain topology: Cylindrical brushes and dendrimers. Macromolecules 2007, 40, 7998-8006. [CrossRef]

24. Wang, Y.; Zhang, X.; Yang, G. Single molecular analysis of the interaction between DNA and chitosan. RSC Adv. 2015, 5, 29594-29600. [CrossRef]

25. Kabanov, V.; Sergeyev, V.; Pyshkina, O.; Zinchenko, A.; Zezin, A.; Joosten, J.; Brackman, J.; Yoshikawa, K. Interpolyelectrolyte complexes formed by DNA and astramol poly(propylene imine) dendrimers. Macromolecules 2000, 33, 9587-9593. [CrossRef]

26. Walker, H.W.; Grant, S.B. Factors Influencing the flocculation of colloidal particles by a model anionic polyelectrolyte. Colloids Surf. 1996, 119, 229-239. [CrossRef]

27. Keren, K.; Soen, Y.; Yoseph, G.B.; Gilad, R.; Braun, E.; Sivan, U.; Talmon, Y. Microscopics of complexation between long DNA molecules and positively charged colloids. Phys. Rev. Lett. 2002, 89, 088103. [CrossRef] [PubMed]

28. Gössl, I.; Shu, L.; Schlüter, A.D.; Rabe, J.P. Molecular structure of single DNA complexes with positively charged dendronized polymers. J. Am. Chem. Soc. 2002, 124, 6860-6865. [CrossRef] [PubMed]

29. Wang, Y.; Kimura, K.; Huang, Q.; Dubin, P.L.; Jaeger, W. Effect of salt on polyelectrolyte-micelle coacervation. Macromolecules 1999, 32, 7128-7134. [CrossRef]

30. Fu, W.-B.; Wang, X.-L.; Zhang, X.-H.; Ran, S.-Y.; Yan, J.; Li, M. Compaction dynamics of single DNA molecules under tension. J. Am. Chem. Soc. 2006, 128, 15040-15041. [CrossRef] [PubMed]

31. Raspaud, E.; de la Cruz, M.O.; Sikorav, J.-L.; Livolant, F. Precipitation of DNA by polyamines: A polyelectrolyte behavior. Biophys. J. 1998, 74, 381-393. [CrossRef]

32. Pelta, J.; Livolant, F.; Sikorav, J.-L. DNA aggregation induced by polyamines and cobalthexamine. J. Biol. Chem. 1996, 271, 5656-5662. [CrossRef] [PubMed]

33. Todd, B.A.; Rau, D.C. Interplay of ion binding and attraction in DNA condensed by multivalent cations. Nucleic Acids Res. 2008, 36, 501-510. [CrossRef] [PubMed] 
34. Cherstvy, A.G. Electrostatic interactions in biological DNA-related systems. Phys. Chem. Chem. Phys. 2011, 13, 9942-9968. [CrossRef] [PubMed]

35. Cortini, R.; Caré, B.R.; Victor, J.-M.; Barbi, M. Theory and simulations of toroidal and rod-like structures in single-molecule DNA condensation. J. Chem. Phys. 2015, 142, 105102. [CrossRef] [PubMed]

36. Martín-Molina, A.; Calero, C.; Faraudo, J.; Quesada-Pérez, M.; Travesset, A.; Hidalgo-Álvarez, R. The hydrophobic effect as a driving force for charge inversion in colloids. Soft Matter 2009, 5, 1350-1353. [CrossRef]

37. Wang, Y.; Ran, S.; Man, B.; Yang, G. Ethanol induces condensation of single DNA molecules. Soft Matter 2011, 7, 4425-4434. [CrossRef]

38. Todd, B.A.; Parsegian, V.A.; Shirahata, A.; Thomas, T.; Rau, D.C. Attractive forces between cation condensed DNA double helices. Biophys. J. 2008, 94, 4775-4782. [CrossRef] [PubMed]

39. Strick, T.; Allemand, J.-F.; Bensimon, D.; Croquette, V. Behavior of supercoiled DNA. Biophys. J. 1998, 74, 2016-2028. [CrossRef]

40. Estévez-Torres, A.; Baigl, D. DNA Compaction: Fundamentals and applications. Soft Matter 2011, 7, 6746. [CrossRef]

(C) 2017 by the authors. Licensee MDPI, Basel, Switzerland. This article is an open access article distributed under the terms and conditions of the Creative Commons Attribution (CC BY) license (http:/ / creativecommons.org/licenses/by/4.0/). 